\title{
ABNORMAL TOOTH WEAR CAUSED BY TOOL USE FOUND IN THE CEMETERY OF SZALASZEND, HUNGARY, DATED TO THE PERIOD OF THE HUNGARIAN CONQUEST (10TH C.)
}

\author{
Orsolya Mateovics-LÁsZló ${ }^{1}$ - Csilla LíBOR ${ }^{2}$ \\ Hungarian Archaeology Vol. 10 (2021), Issue 1, pp. 22-29. https://doi.org/10.36338/ha.2021.1.4
}

The Archaeological Heritage Directorate of the Hungarian National Museum conducted excavations in 2018 preceding the construction of motorway M30. The site of Szalaszend-Kis-és Nagyhegy in north-east Hungary is located south of a Bronze Age earth mound. Only a few burials were brought to light from the 10 th century, however, this assemblage revealed a fair amount of valuable archaeological and anthropological data. From an anthropological point of view, burial no. SNR407 was most significant, as these remains offered a glimpse into the lifestyle of this 10th-century population. The abnormal wear observed on the enamel of a front tooth of the male individual can be interpreted as a sign of a tooth-tool use, suggesting an activity when a hard object is held by the teeth during an activity that requires the use of both hands.

Keywords: anthropology, burial, early medieval, Hungarian Conquest, lifestyle, tooth wear

The advancement of anthropological research methods and the ever-growing dataset of examined burials facilitate the discovery of exceptional cases that raise yet unexplored questions. Such a finding urged us to look at a research topic that is rarely touched upon in Hungary, i.e., dental pathologies that suggest certain types of tool use during the individual's life. Morphological changes that point to certain activities (enthesopathies, disorders involving the attachment of tendons, ligaments or components of a joint onto the bone) have been well researched, and sometimes it is possible to define the exact type of physical activity that caused a specific morphological change of the bones. Mounted lifestyle and archery are among such activities (TinANYI et al. 2015). Although less often, the pathologies of teeth can also be suggestive of actions during the individual's lifetime, that is, they have the potential to reveal information beyond nutrition. Such dental pathologies usually manifest in the form of irregular tooth wear and suggest physical damage due to tool use. In early modern populations, occupations such as shoemaking or carpentry can be testified to by these phenomena (Bonfiglioli et al., 2004); a spectacular example is a 30-40-year-old man from England who probably worked as a carpenter and the habit of holding nails that had a rectangular cross-section with his teeth caused deep, concave abrasions on the sides of his incisors (TURNER \& ANDERSON 2003).

The site of Szalaszend-Nagy- és Kishegy, dated to the period of the Hungarian Conquest, offered an excellent opportunity to gain insight into the everyday life of a past population in this unique way. At the same time, this is the first time this type of dental pathology is registered in Hungary and from this period.

\section{THE SITE}

The 10th-century burial site is on a hill on the western edge of the Hernád Valley, on the southern bank of a one-time temporary watercourse (Líbor \& TAKÁcs, 2019; TAKÁcs \& Pusztai, 2019; SzÖRényi \& PuszTai et al., 2020) (Figs 1-2). In all these burials, the bones were poorly preserved. The graves must have been damaged by contemporary robbing, and therefore the skeletons were only partial and various elements were missing. In all cases, the robber pit targeted the upper body and the pelvic area. Among the eight burials, there were three men, two women, one child, and two individual's sex could not be determined; most of them died as adults or at a mature age.

\footnotetext{
Hungarian National Museum, Archaeological Heritage Protection Directorate, Budapest. E-mail: laszlo.orsolya@hnm.hu

King St. Stephen Museum, Székesfehérvár; Eötvös Loránd University, Doctoral School of Biology. E-mail: libor.csilla@szikm.hu
} 


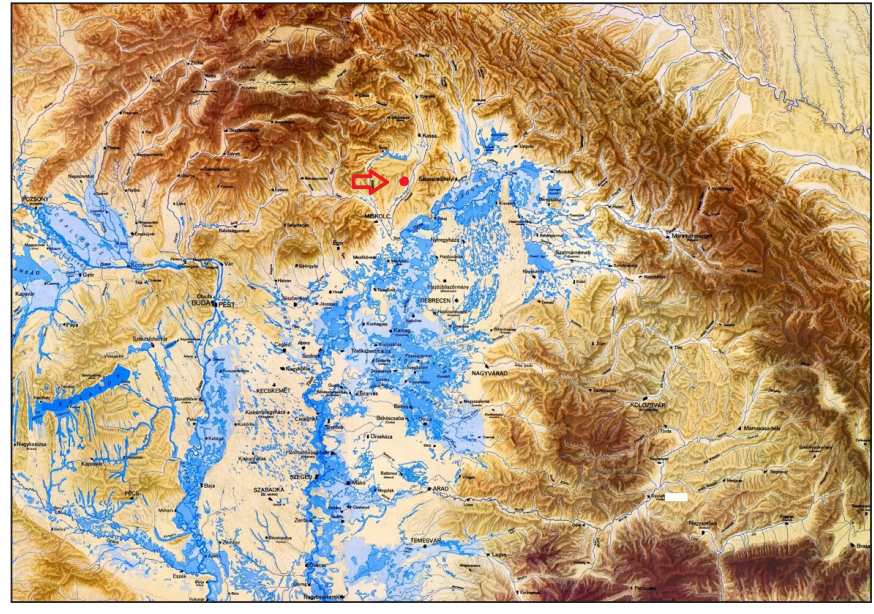

Fig. 1. The location of the site

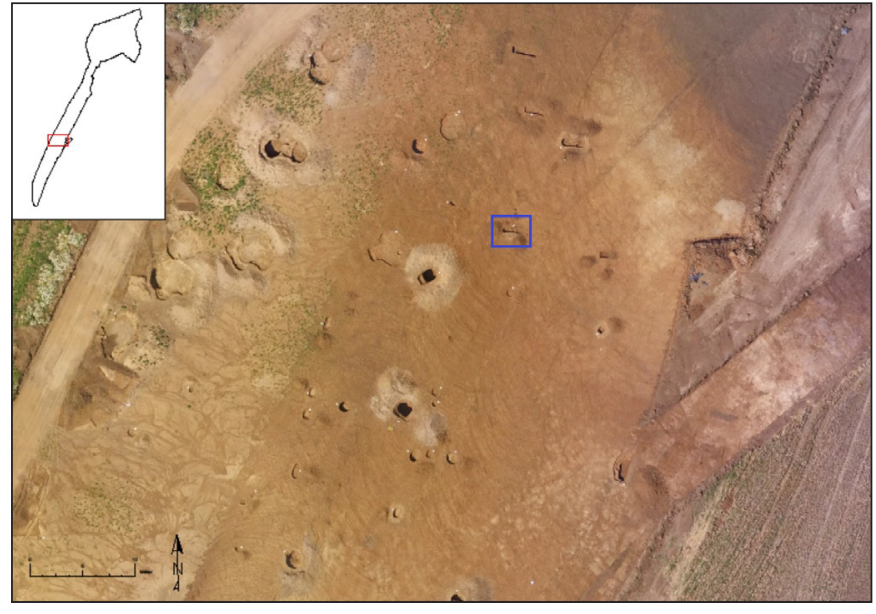

Fig. 2. Aerial photo of the site (by László Pokorni)

\section{INDIVIDUAL SNR407}

This grave belonged to a man, 23-27 years of age (ÉRY \& KRALOVÁNYSZKY 1963; LoveJOY et al. 1985; Suchey \& BRooks 1990), whose remains were poorly preserved (Figs 3-4). Pieces of the skull and some bones of the skeleton were missing. The body was found in a supine position, with the bones of the legs in anatomic order, while the skull was found in the belly region. No robber pit was identified. A rectangular silver sheet came to light from under the pelvis, with traces of gilding. Its function remains unknown but, in all probability, it was a belt mount. The bone plate of a bow's grip was found among the skeletal remains (Fig. 4). No pathological phenomenon was observed on the skull and the bones.

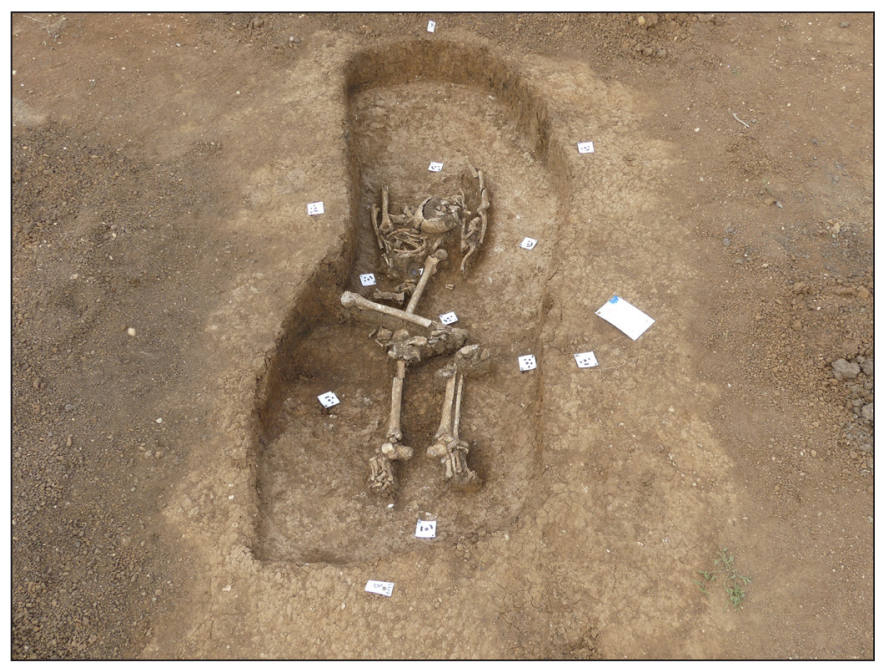

Fig. 3. Photo documentation of Grave SNR407 (photo by Csilla Libor)

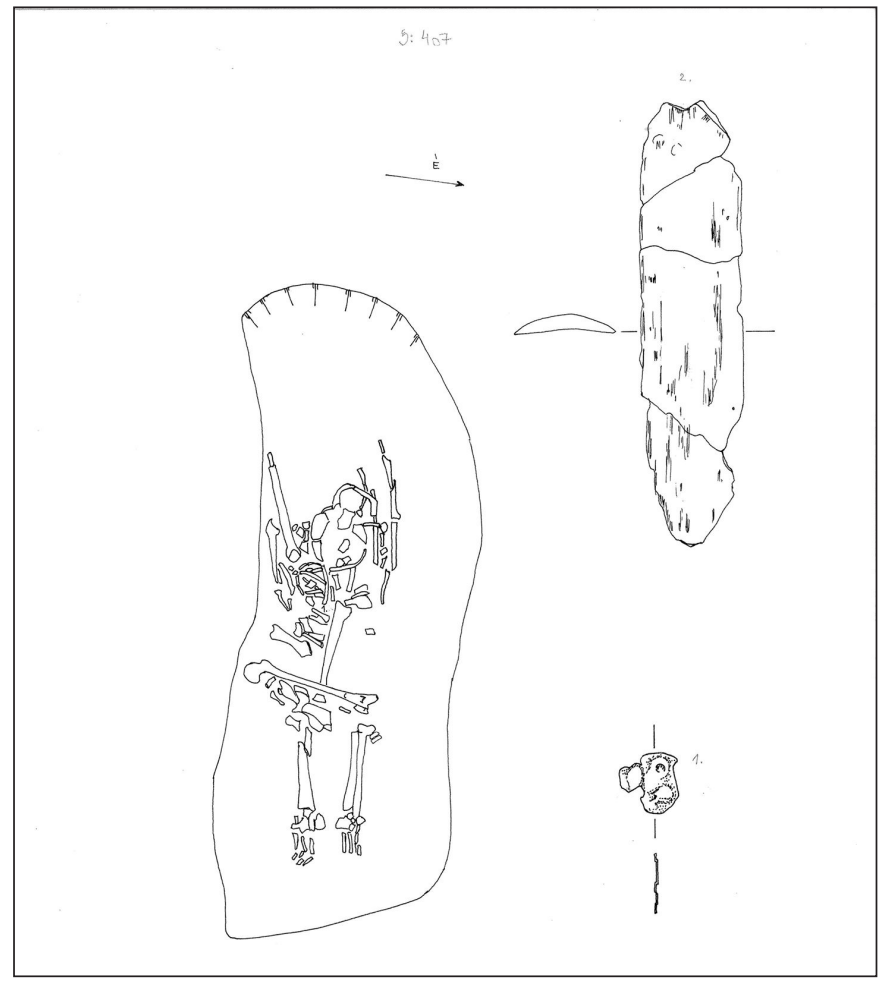

Fig. 4. Drawing of Grave SNR407, with details of the ovalshaped bow grip made from bone (drawing by Csaba Szénásy and Ágnes Kazsóki)

\section{A DETAILED ANALYSIS OF THE TEETH}

Both upper third molars and the upper right second molar are missing; these fell out postmortem. The remaining teeth display wear that correlates with the person's age, with the exception of the first molars that are more heavily worn, the dentin being exposed in patches. The lower left second incisor shows a unique 


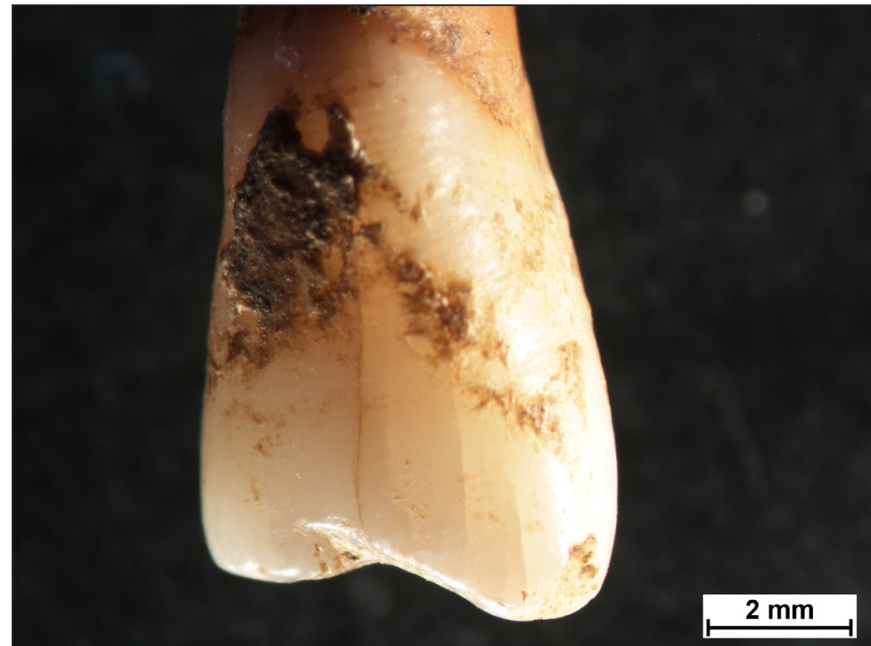

Fig. 5. The second left incisor viewed from the labial side, with the wear pattern induced by an object

wear pattern: the wear is perpendicular to the tooth's edge (buccal-labial orientation) and is strongest in the middle, exposing the dentin under the enamel. On the labial side, the depression widens in the direction of the edge in a V-shape, and the apex of the ' $\mathrm{V}$ ' turns slightly to the left (Figs 5-6). On the lingual side, the groove is curved downwards, the edge is sharp, and the wear is arranged into a lacelike pattern with small curves (Figs 7-9). The worn surface is yellowish, suggesting a discoloration by the soil, which means that the wear pattern is not due to postmortem damages to the tooth. The wear must have developed before the man died.

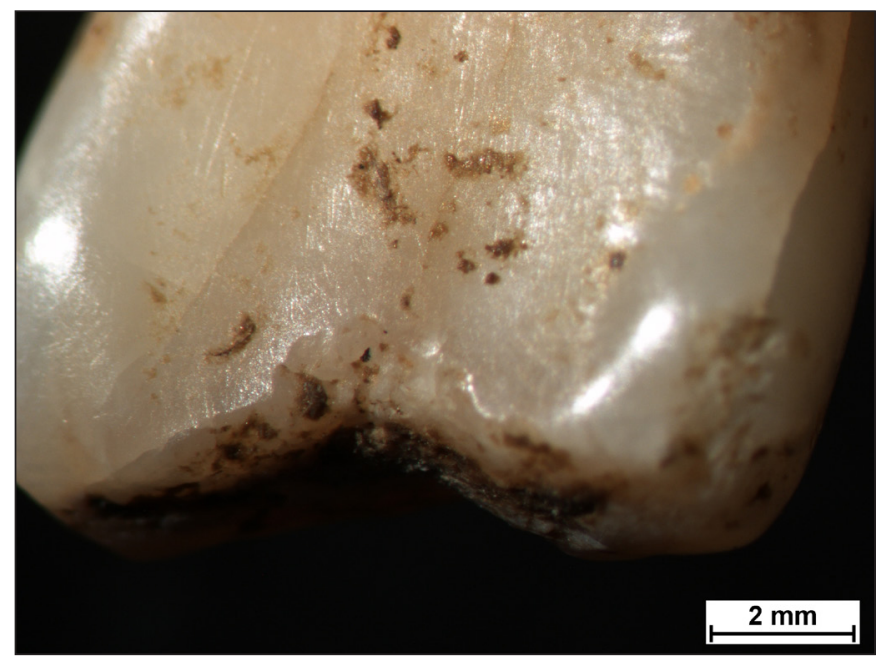

Fig. 6. Wear on the edge of the incisor, viewed from the labial side

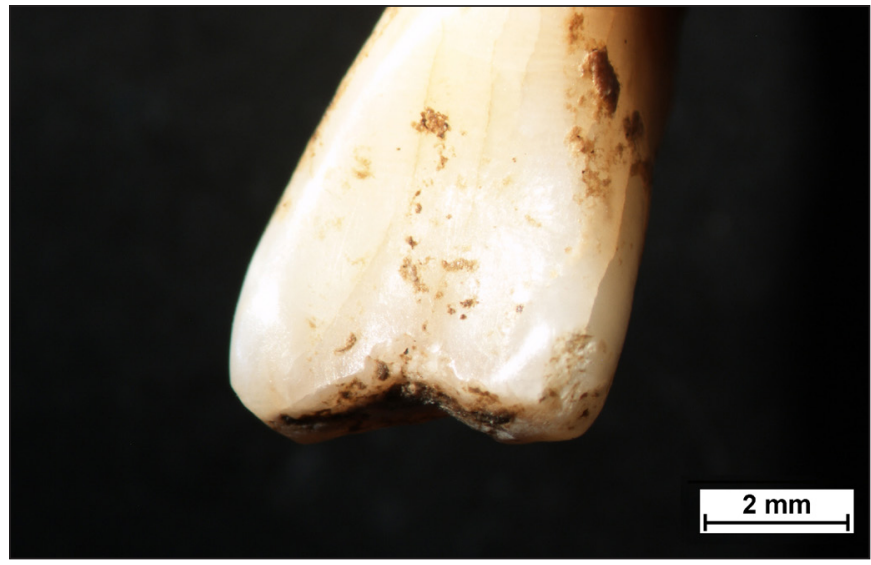

Fig. 7. The second left incisor viewed from the lingual side, with the wear pattern induced by an object

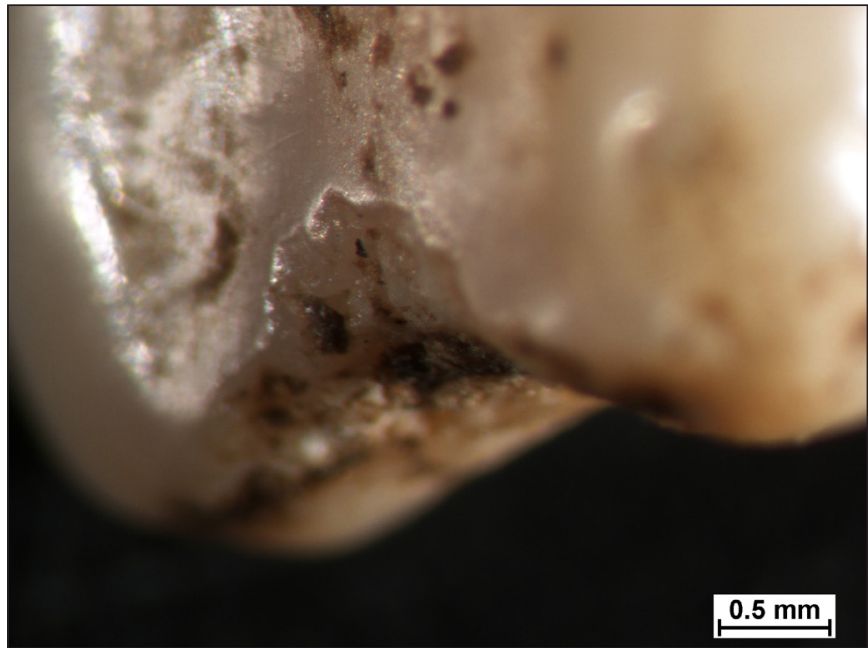

Fig. 8-9. Wear on the edge of the incisor, viewed from the lingual side

\section{TEETH AS INDICATORS OF LIFESTYLE}

As we age, our teeth continue to be worn, and the pattern and measure of wear highly depend on what we eat. Tooth wear first creates small, polished patches on the enamel, and later on the dentin, which is nor- 
mally protected by the enamel, can get exposed, and even the root may be affected. Tooth wear is caused by three main processes: attrition, erosion, and abrasion.

Attrition is the normal, non-pathological wear that appears on all teeth as part of the ageing process (Hillson 1996). In addition to the wear induced by food consumption, the loss of dental tissues may be caused by heavy mastication or bruxism as well, as a consequence of tooth-to-tooth contact. Incisors usually display a mesial-labial wear pattern (i.e., oriented from the middle towards the sides), which is caused by the contact of the upper and the lower incisors. Malocclusion, underbite and overbite may influence the wear, and in such cases the wear typically appears on the lingual or on the labial side of the tooth instead of its edge. Of course, individual patterns can occur as well, especially in cases of a developmental deficiencies (overcrowding or abnormal development of dentition), but these can be unambiguously identified based on the position of the teeth in the jaw. However, the wear on the tooth of the Szalaszend individual differs in its character and orientation from the general wear pattern and therefore it is certainly not due to tooth-to-tooth contact.

Erosion can also be excluded from the causes, because erosion is a chemical dissolution of the tooth substance caused by acids, such as reflux, frequent vomiting, or, in modern populations, the consumption of carbonated drinks (HILLSON 1996).

The morphology of the tooth wear in the Szalaszend man suggests that the enamel was worn down by a mechanical interaction with a thin but solid substance that was rubbed against the edge of the tooth in one direction. This is a special form of abrasion. Abrasion is not a normal wear caused by mastication but the loss of dental tissue due to a repetitive activity done with the teeth or due to frequent interactions with an object. There are four categories of abrasion, (1) deliberate mutilation, (2) non-deliberate wear caused by an object, (3) abrasion caused by habits related to dental hygiene, and (4) occupation-related abrasion.

1. Deliberate mutilation can easily be mistaken for object-induced wear, but these are made on aesthetical or symbolic grounds. Such deliberate abrasion patterns are known from the Viking period (ARCINI 2020), and lip jewelleries worn by certain populations on the American continent can also cause such deformations (CYBULSKI, 1974; Torres-RoufF, 2003).

2. Non-deliberate abrasion caused by objects is associated with tools, other than cutlery, being held in or moved with the mouth. A typical example for this is the so-called pipe facet, a circular/semi-circular wear pattern that has been observed on individuals in Europe from the 18th century onwards. This wear pattern is also present in Hungary, in the 16th-17th-century

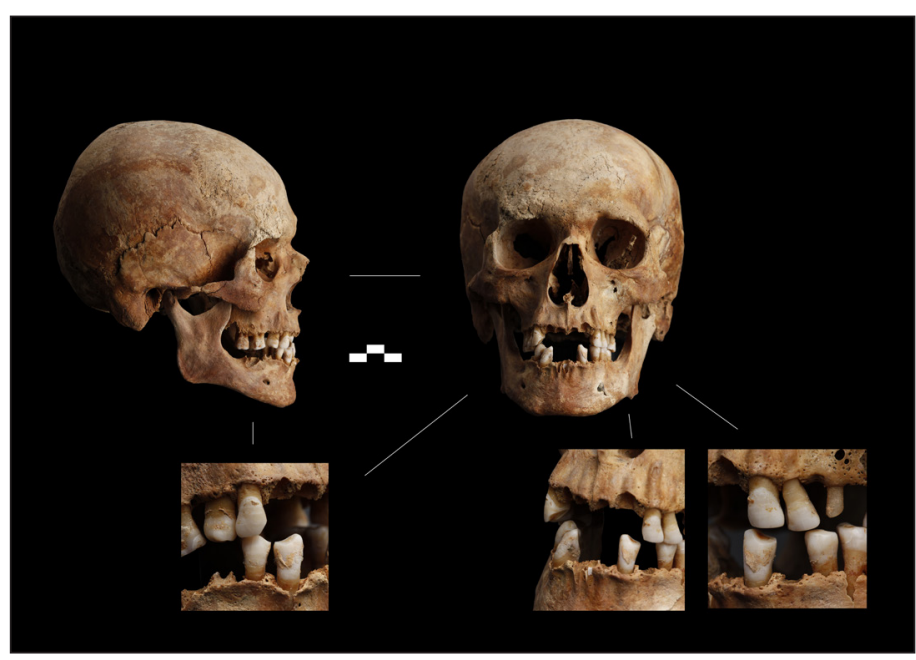

Fig. 10. So-called pipe facet, an oval-shaped wear from the Serbian cemetery of Perkáta-Nyúli dülö. The wear developed on the upper and lower right premolars and canines. On the left side, the lower canine displays similar wear (SNR2024, 30-39-year-old male; photo by József Bicskei, HNM) Serbian cemetery of Perkáta-Nyúli dülő (Mateovics-László, yet unpublished) (Fig. 10) (KvaAl \& Derry 1996). In modern populations, toothbrushes or certain musical instruments can cause similar deformations.

3. So-called interproximal grooves, reported even in Hominids (FrAYER \& RUSSELL 1987; BERMUDEZ DE CASTRO et al. 1997), may appear between neighbouring teeth at the cementum-enamel junction and are probably related to tooth-picking behaviours (BERRYMAn et al. 1979; FrAYER 1991).

4. Deformations related to occupations are usually caused by activities in which both hands are needed, and a hard object is held or moved with the teeth (CRUwYs et al. 1992). Undoubtedly, this was the case with the Szalaszend individual. 


\section{ANALOGIES - IS THERE AN EXPLANATION?}

Research into dental pathologies in Hungary usually covers nutrition-related problems and non-metric variations, developmental deficiencies (Kocsis 1988; SzIKossy \& Bernert 1996; Maczel et al. 1998). So far, no tool use-related deformations have been published from Hungary, and such cases are sporadically reported from abroad as well. Tooth wear caused by tool use has a specific morphology and appears on different locations in the teeth row depending on the activity, and therefore, it is the recorded and published cases that can help with identifying the specific activity behind a wear pattern.

Deformations on the tooth of the Szalaszend male bear similarities in terms of both morphology and localization with cases when the grooves were caused by fibres moved between or held with the teeth, during the processing of vegetable or animal fibres (LARSEN 1985; Molleson 1994). In these cases, the incisors, the canines, and the premolars were affected.

Pulling vegetable or animal fibres between the teeth can result in approximal grooves at the neck of premolars and molars, or on the edge of incisors, but then the grooves run parallel to the incisor's edge (BROWN \& Molnar 1990; Milner \& LARSEN 1991). This was observed on the remains of 19th-century Australian aboriginals, mostly men. The hypothesis was confirmed by documentaries that filmed aboriginals during this activity (BROwn \& MolnaR, 1990).

In a Precolumbian assemblage, approximal grooves and wear on the incisal ridge of the incisors were interpreted as a result of plant fibre processing, e.g. basket weaving or net making (SCHULz 1977; LARSEN 1985). According to a comprehensive British study, tooth wear of this type was found on teeth from the Anglo-Saxon period as well (CRUwYs et al. 1992). In both cases, this form of tooth wear was more typical for males than females. In the Cuman cemetery of Perkáta-Nyúli dülö (13th-16th century), similar V-shaped grooves were observed on the lower incisors of three women (Mateovics-László, yet unpublished). In the latter case the grooves were thin but deep (Fig. 11).

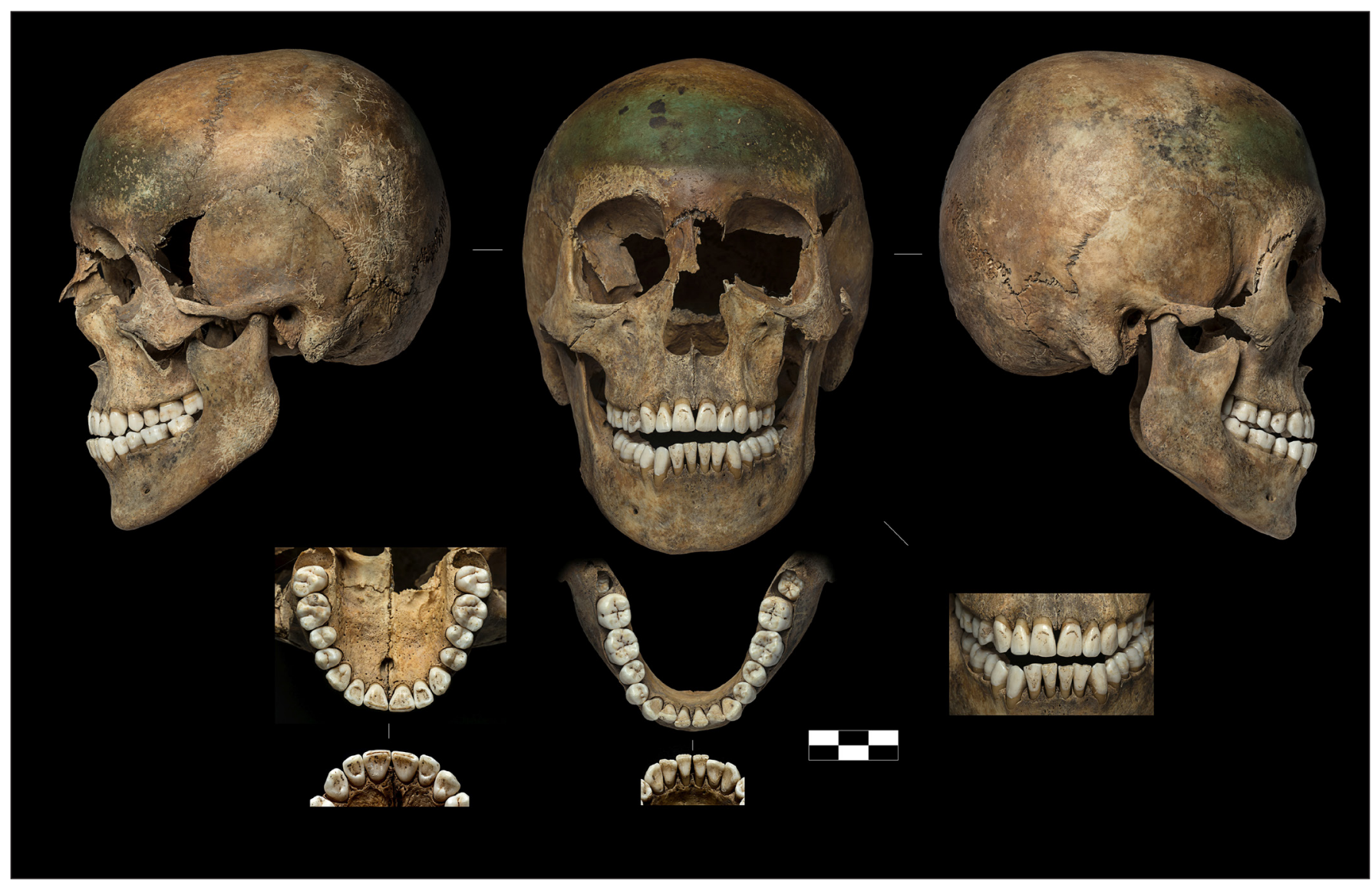

Fig. 11. V-shaped groove on the lower left second incisor of a 15-17-year-old female from the Cuman cemetery of Perkáta-Nyúli dülö (SNR1038) (photo by József Bicskei, HNM) 
One can use his teeth also while producing threads from wool, hemp, or flax. Making the thread involves pulling and rotating the raw fibres to produce a continuous thread, ready to be yarned, from the individual fibres that have a limited length (EMERY 1994). Removing dirt and fluffs from the wool is an important step before the thread is spun, because dirt and fluffs would make the thread uneven and difficult to work with. This was done with the teeth, because both hands were needed to spin the thread. During sewing, the same way of pulling and biting may be used to cut the thread (SCOTT \& JoLIE 2008). Weaving and spinning were usually women's work, and therefore it can be hypothesised that a different activity caused the morphological changes on the tooth of the male from Szalaszend. Ray Wood (1992) observed a similar phenomenon in Inuit Eskimo populations, where grooves running perpendicular to the incisors' edge were caused by holding between the teeth pins and fibres (women), or animal tendons (men). Many cultures use animal tendons (e.g. for making ropes or bowstrings) (SCOTT \& TURNER 1988). Taking into consideration that there was an archery-related object in the Szalaszend grave, it cannot be excluded that this man from the Hungarian Conquest period was active in making such objects or in preparing raw material for them.

\section{IS HE THE ONLY ONE?}

Although the cemeteries of Szalaszend and Perkáta are associated with different populations and the two burial grounds were used in different time periods, both populations have eastern roots. These findings demonstrate that traces of unique activities are present in both the Szalaszend and Perkáta populations, irrespective of the period, as they reflect similarities in lifestyle and customs. In addition to examining more bodies from the Hungarian Conquest period and from Cuman contexts, further research on Avar cemetery assemblages that show eastern connections has the potential to reveal new information on these phenomena.

\section{BIBLIOGRAPHY}

Arcini, C. (2020). Intentionally Modified Teeth Among the Vikings: Was It Painful? In S. Sheridan \& L. Gregoricka (eds.), Purposeful Pain. Bioarchaeology and Social Theory (pp. 137-148). Springer, Cham. https://doi.org/10.1007/978-3-030-32181-9 7

Bermudez de Castro, J. M., Arsuaga, J. L. \& Perez, P. J. (1997). Interproximal grooving in the AtapuercaSH Hominid dentitions. American Journal of Physical Anthropology 102, 369-376. https://doi.org/10.1002/ (sici)1096-8644(199703)102:3\%3C369::aid-ajpa6\%3E3.0.co;2-q

Berryman, H. E., Owsley, D. W. \& Henderson, A. M. (1979). Noncarious interproximal grooves in Arikara Indian dentitions. American Journal of Physical Anthropology 50, 209-212. https://doi.org/10.1002/ ajpa. 1330500209

Bonfiglioli, B., Mariotti, V., Facchini, F., Belcastro, M. G. \& Condemi, S. (2004). Masticatory and nonmasticatory dental modifications in the Epipalaeolithic necropolis of Taforalt (Morocco). International Journal of Osteoarchaeology 14, 448-456. https://doi.org/10.1002/oa.726

Brooks, S. \& Suchey, J. M. (1990). Skeletal age determination based on the os pubis: A comparison of the Acsádi-Nemeskéri and Suchey-Brooks methods. Human Evolution 5, 227-238. https://doi.org/10.1007/ $\underline{B F 02437238}$

Brown, T. \& Molnar, S. (1990). Interproximal grooving and task activity in Australia. American Journal of Physical Anthropology 81, 545-553. http://doi.org/10.1002/ajpa.1330810410 
Orsolya Mateovics-László - Csilla Líbor • Abnormal Tooth Wear Caused by Tool Use

Cruwys, E., Robb, N. D. \& Smith, B. G. N. (1992). Anterior tooth notches: An Anglo-Saxon case study. Journal of Paleopathology 4, 211-220.

Cybulski, J. S. (1974). Tooth wear and material culture: Precontact patterns in the Tsimshian area, British Columbia. Syesis 7, 31-35.

Emery, I. (1994). The Primary Structures of Fabrics: An Illustrated Classification. Watson Guptill Publications - Whitney Library of Design, the Textile Museum, Washington, D.C.

Éry, K., Kralovánszky, A. \& Nemeskéri, J. (1963). Történeti népességek rekonstrukciójának reprezentációja [How the reconstruction of ancient populations is represented]. Anthropológiai Közlemények 7, 41-90.

Formicola, V. (1988). Interproximal grooving of teeth: Additional evidence and interpretation. Current Anthropology 29 (4), 663-671.

Frayer, D. W. (1991). On the etiology of interproximal grooves. American Journal of Physical Anthropology 85, 299-304. https://doi.org/10.1002/ajpa.1330850308

Frayer, D. W. \& Russell, M. D. (1987). Artificial grooves on the Krapina Neanderthal teeth. American Journal of Physical Anthropology 74, 393-405. https://doi.org/10.1002/ajpa.1330740311

Hillson, S. (1996). Dental Anthropology. Cambridge: Cambridge University Press. https://doi.org/10.1017/ CBO9781139170697

Kocsis, S. G. (1988). Hódmezővásárhely Gorzsa-Czukor major újkőkori temető embertani anyagának fogantropológiai és patológiai leírása [Dental anthropology and pathology in the Neolithic cemetery of Hódmezővásárhely Gorzsa-Czukor major]. A Móra Ferenc Múzeum Évkönyve 1987 (1), 69-79.

Kvaal, S. I., Derry, T. K. (1996). Tell-tale teeth: abrasion from the traditional clay pipe. Endeavour 20 (1), 28-30. https://doi.org/10.1016/0160-9327(96)10006-5

Larsen, C. S. (1985). Dental modifications and tool use in the western Great Basin. American Journal of Physical Anthropology 67 (4), 393-402. https://doi.org/10.1002/ajpa.1330670411

Libor, Cs. \& Takács, R. (2019). The conquerors of the Hernád Valley - Details from the history of a region. Hungarian Archaeology 8 (3), 28-34. https://doi.org/10.36338/ha.2019.3.9

Lovejoy, C. O., Meindl, R. S., Mensforth, R. P. \& Barton, T. J. (1985). Multifactorial determination of skeletal age at death: A method with blind tests of its accuracy. American Journal of Physical Anthropology 68 (1), 1-14. https://doi.org/10.1002/ajpa.1330680102

Lozano, M., Jiménez-Brobeil, S. A., Willman, J. C., Sánchez-Barba, L.P., Molina, F. \& Rubio Á. (2020). Argaric craftswomen: Sex-based division of labor in the Bronze Age southeastern Iberia. Journal of Archaeological Science. In press, corrected proof. https://doi.org/10.1016/j.jas.2020.105239

Maczel M., Kocsis S.G., Marcsik A., Molnár E. (1998). Dental disease in the Hungarian conquest period. Bulletins et Mémoires de la Société d'anthropologie de Paris, Nouvelle Série 10 (3-4), 457-470. https:// doi.org/10.3406/bmsap.1998.2530 
Orsolya Mateovics-László - Csilla Líbor • Abnormal Tooth Wear Caused by Tool Use

Milner, G. R. \& Larsen, C. S. (1991). Teeth as Artifacts of Human Behavior: Intentional Mutilation and Accidental Modification. In M. A. Kelley and C. S. Larsen (eds.), Advances in Dental Anthropology (pp. 357-378). New York: Wiley-Liss.

Molleson, T. (1994). The eloquent bones of Abu Hureyra. Scientific American 271 (2), 70-75. https://doi. org/10.1038/ scientificamerican0894-70

Ray-Wood, S. (1992). Tooth wear and sexual division of labour in an Inuit population. BA thesis. Simon Fraser University, Department of Archaeology.

Schulz, P. D. (1977). Task activity and anterior tooth grooving in prehistoric California Indians. American Journal of Physical Anthropology 46, 87-92. https://doi.org/10.1002/ajpa.1330460112

Scott, G. R. \& Jolie, R. B. (2008). Tooth-tool use and yarn production in Norse Greenland. Alaska Journal of Anthropology 6 (1-2), 253-264.

Scott, G. R. \& Turner, C. G. (1988). Dental Anthropology. Annual Review of Anthropology 17, 99-126. https://doi.org/10.1146/annurev.an.17.100188.000531

Szikossy, I. \& Bernert, Zs. (1996). A Kereki-Homokbánya temető paleosztomatológiai vizsgálata (Paleostomatological study of the Avar Age cemetery at Kereki-Homokbánya). In Gy. Farkas \& Gy. Pálfi (eds.) Honfoglaló magyarság - Árpád kori magyarság (pp. 189-198). Szeged: JATE Embertani tanszék.

Szörényi, G. \& Pusztai, T. (2020). Hét metszet a Hernád folyó völgyéböl. Az M30-as Miskolc-Kassa autópálya építését megelőző régészeti feladatellátás és kutatás [Seven sections of the Hernád Valley. Archaeological research preceding the construction of the M30 motorway between Miskolc and Košice]. Herman Ottó Múzeum Évkönyve 2020, 103-148.

Takács, R. \& Pusztai, T. (2019). A Hernád-völgy 10-11. századi településtörténetéhez [On the 10th11th-century settlement history of the Hernád Valley]. In B. Sudár \& A. Türk (eds.), „Hadak útján”-A népvándorláskor fiatal kutatóinak XXIX. Konferenciája. Budapest, 2019. november 15-16. Absztrakt kötet (pp. 86-87). Budapest: Bölcsészettudományi Kutatóközpont Magyar Östörténeti Témacsoport - Pázmány Péter Katolikus Egyetem Régészettudományi Intézet - Martin Opitz Kiadó.

Tiesler, V., Cucina, A. \& Ramirez-Salomon, M. (2017). Permanent Dental Modifications among the Ancient Maya: Procedures, Health Risk, and Social Identities. In S. E. Burnett \& J. D. Irish (eds.), A World View of Bioculturally Modified Teeth (pp. 270-284). Gainesville: University Press of Florida.

Tihanyi, B., Bereczki, Zs., Molnár, E., Berthon, W., Révész, L., Dutour, O. \& Pálfi, Gy. (2015). Investigation of Hungarian Conquest Period (10th c. AD) archery on the basis of activity-induced stress markers on the skeleton - preliminary results. Acta Biologica Szegediensis 59 (1), 65-77.

Torres-Rouff, C. (2003). Oral implications of labret use: A case from pre-Columbian Chile. International Journal of Osteoarchaeology 13, 247-251. https://doi.org/10.1002/oa.691

Turner, G., Anderson, T. (2003). Marked occupational dental abrasion from medieval Kent. International Journal of Osteoarchaeology 13, 168-172. https://doi.org/10.1002/oa.646 